\section{Effect of size and surrounding forest vegetation on chemical properties of soil in forest gaps}

\author{
Mehmet Özcan ${ }^{(1)}$, Ferhat Gökbulak ${ }^{(2)}$
}

Forest gaps have different microclimatic conditions as compared to the surrounding areas, depending on gap size and surrounding forest types and affecting the biological, chemical, physical, and hydrological processes in the forest openings. The objective of this study was to determine the effect of forest gap size and surrounding forest cover type (beech or mixed stands) on the soil of forest opening by analyzing several soil chemical soil properties $(\mathrm{pH}$, electrical conductivity - EC, organic matter - OM, and nutrient content). The study was conducted in the Yuvacik watershed in Izmit (Turkey) and a total of $\mathbf{3 1}$ forest gaps of different size (1.44-37.33 ha) and elevations (848-1169 $\mathrm{m}$ a.s.l.) were studied. Gaps were divided into three groups with size 0-5 ha, 5-15 ha, and $>15$ ha. Results showed that forest gap size significantly affected all the investigated chemical properties of the soil, except for soil $\mathrm{pH}$. As gap size increased, sodium $\left(\mathrm{Na}^{+}\right)$concentration in the soil decreased from 22.72 to 19.57 mg L $\mathrm{L}^{-1}$ while potassium $\left(\mathrm{K}^{+}\right)$and magnesium $\left(\mathrm{Mg}^{+2}\right)$ concentrations increased from 83.88 to $134.62 \mathrm{mg} \mathrm{L}^{-1}$ and from 59.46 to $123.96 \mathrm{mg} \mathrm{L}^{-1}$, respectively. Medium-sized gap soils had the lowest OM content, as well as the lowest calcium $\left(\mathrm{Ca}^{+2}\right)$ and nitrogen $\left(\mathrm{N}^{+3}\right)$ concentrations. Surrounding forest types significantly influenced soil chemical properties in the openings, except for $E C, \mathrm{~N}^{+3}$, and phosphorus $\left(\mathrm{P}_{-} \mathrm{PO}_{4}^{-3}\right)$. Soils in the gaps surrounded by mixed forest had significantly lower $\mathrm{pH}$ but higher $\mathrm{OM}$ content, $\mathrm{K}^{+}, \mathrm{Na}^{+}, \mathrm{Ca}^{+2}$, and $\mathrm{Mg}^{+2}$ concentrations than soils in beech forest gaps.

Keywords: Forest Openings, Forest Ranges, Plant Nutrients, Soil Chemistry, Forest Soils

\section{Introduction}

Forest openings are special habitats differing from the surrounding forest environment and having a significant effect on forage production (Frost \& Edinger 1991, Fernald et al. 2009), plant diversity and species composition (Rhoades et al. 2004, Galhidy et al. 2006, Chunyu \& Xiuhai 2007), seedling establishment and growth (Muscolo et al. 2010), climatic parameters (Ritter et al. 2005), and soil chemical properties (Chunyu \& Xiuhai 2007, Scharenbroch \& Bockheim 2007, Thiel \& Perakis 2009). Gap size influences especially ambient and soil temperatures, solar radiation, wind speed, and soil

moisture. Carlson \& Groot (1997) reported that both seasonal average soil temperatures and soil temperature extremes increased as gap size increased and greater temperature extremes occurred in larger openings. Similarly, Fernald et al. (2009) found greater soil moisture, soil and air temperatures in the interspaces than underneath dead and alive tree canopies. Similar results were also reported in other studies (Morecroft et al. 1998, Ritter et al. 2005, Scharenbroch \& Bockheim 2007, Renaud \& Rebetez 2009). Soil moisture and temperature affect not only litter decomposition but also other processes occurring in the soil. Muscolo et al.

(1) Faculty of Forestry, Department of Watershed Management, Düzce University, 81620 Düzce (Turkey); (2) Faculty of Forestry, Department of Watershed Management, Istanbul University, 34473 Bahçeköy, Istanbul (Turkey)

@ Mehmet Özcan (mehmetozcan@duzce.edu.tr)

Received: Dec 20, 2012 - Accepted: Feb 15, 2014

Citation: Özcan M, Gökbulak F, 2015. Effect of size and surrounding forest vegetation on chemical properties of soil in forest gaps. iForest 8: 67-72 [online 2014-06-04] URL:

http://www.sisef.it/iforest/contents/?id=ifor0940-007

Communicated by: Giustino Tonon
(2010) found that medium-sized gaps had a higher soil temperature and photosynthetically active radiation transmittance, and lower soil moisture than small-sized gaps and organic matter $(\mathrm{OM})$ decayed more rapidly in the medium gap than in the small gap. Indeed, higher soil moisture and temperature conditions can favor the rapid decomposition of litter materials and, hence, the nutrient cycling in the openings.

Seedling establishment and plant growth in the forest openings depend not only on the microclimatic conditions within the gaps but also on the distribution of soil nutrients, since the size of the forest gaps has an effect on physical and chemical properties of the soil and on the substrate availability. Chunyu $\&$ Xiuhai (2007) found a positive correlations between gap size and both soil bulk density and total $\mathrm{N}$ content, while negative relations were found between gap size and water content, $\mathrm{OM}$ in litter, and soil $\mathrm{NH}_{4}{ }^{+}$. Muscolo et al. (2007) reported that C (\%), P $(\%)$, and OM contents in the soil decreased significantly as gap size increased. In contrast, Thiel \& Perakis (2009) studied extractable $\mathrm{NH}_{4}^{+}$and $\mathrm{NO}_{3}^{-}$pools, net $\mathrm{N}$ mineralization and nitrification rates, and $\mathrm{NH}_{4}{ }^{+}$ and $\mathrm{NO}_{3}{ }^{-}$ion exchange resin (IER) concentrations in the gaps, finding no significant differences between 0.4 and 0.1 ha gaps for most of the studied parameters. Besides gap size, the surrounding forest cover also plays a significant role in the productivity of forest openings by influencing nutrient dynamics in the soils. Chunyu \& Xiuhai (2007) found that soil OM content, total $\mathrm{N}^{+3}$ and total $\mathrm{K}^{+}$ were greater in the forest gaps than under a Pinus koraiensis canopy. Rhoades et al. (2004) examined the soil properties of forest openings and surrounding forests in Kentucky's Knobs region and reported that soil $\mathrm{pH}$, extractable cations, bulk density, and silt content were higher and extractable $\mathrm{P}$ was lower in the openings compared to the forest soils.

A number of studies have been conducted in forest openings to determine the effect of gap size and the surrounding forest cover on soil chemical properties and nutrient dynamics (Frost \& Edinger 1991, Rhoades et al. 2004, Rezaei \& Gilkes 2005, Scharenbroch $\&$ Bockheim 2007), though the results are not always consistent with each other (Gökbulak \& Özcan 2008). In fact, different tree species in the surrounding canopy have been reported to differently affect the soil chemical characteristics in the gaps (Augusto et al. 1998, Hagen-Thorn et al. 2004, Sariyildiz et al. 2005, Wang \& Wang 2007, Vesterdal et al. 2008, Kooch et al. 2012). Moreover, gap size of the openings analyzed may have determined differences among the results of the aforementioned studies. Furthermore, harvesting practices carried out in the gaps may be 


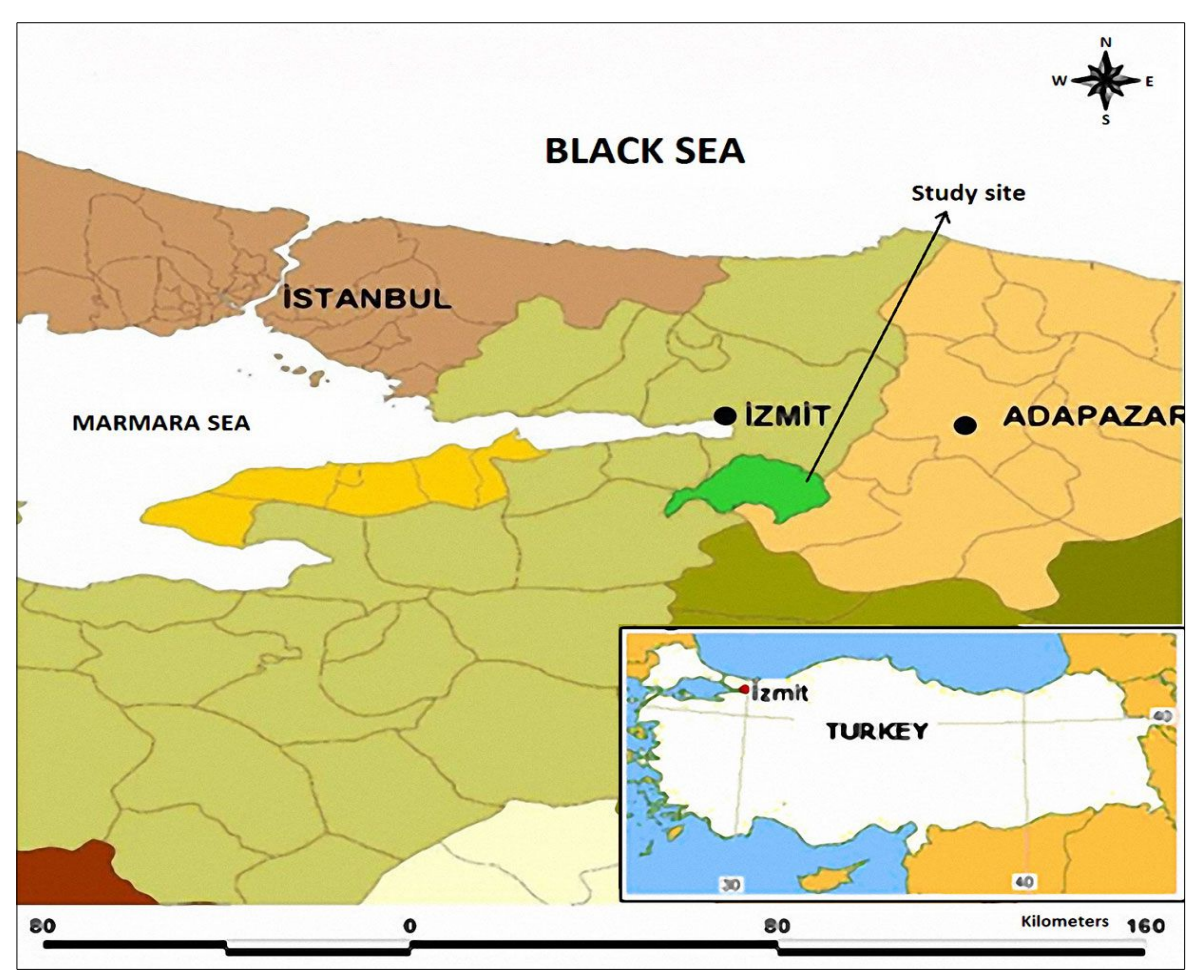

Fig. 1 - Location of the study site.

an additional confounding factor. Indeed, some studies conducted into artificial forest openings (Ritter 2005, Muscolo et al. 2007, 2010) have demonstrated that the soil compaction due to harvesting activities (e.g., logging machines) may affect the hydrological, physical and chemical properties of the soil, as well as the decomposition and mineralization processes, determining an increase in the surface runoff and nutrient leaching, poor aeration, and low moisture capacity and porosity in the soil (Muscolo et al. 2010). Finally, Bartsch (2000) and Scharenbroch \& Bockheim (2007) found that gaps had less cations as compared to the surrounding forest stands due to nutrient leaching.

Limited studies are available in Turkey on soil and herbaceous vegetation characteristics in forest openings (Uluocak 1974, Tekeli \& Mengül 1991, Alan \& Ekiz 2001, Bilgili 2007, Babalik 2008). In this context, the objective of this study was to determine the effect of gap size and the vegetation type in the surrounding forest on selected chemical soil properties ( $\mathrm{pH}, \mathrm{EC}, \mathrm{OM}$ content, and $\mathrm{Na}^{+}, \mathrm{K}^{+}, \mathrm{Ca}^{+2}, \mathrm{Mg}^{+2}, \mathrm{~N}^{+3}, \mathrm{P}_{-} \mathrm{PO}_{4}^{-3}$ concentration) in a broadleaved mixed forest ecosystem.

\section{Material and methods}

\section{Study site}

The study site was located in the Yuvacik watershed in Izmit, Turkey $\left(40^{\circ} 32^{\prime}-40^{\circ} 41^{\prime}\right.$ $\mathrm{N}$ and $29^{\circ} 29^{\prime}-30^{\circ} 08^{\prime} \mathrm{E}$ - Fig. 1). The site has a humid, moderate temperature and oceanic climate with no summer water deficit, according to the Thorntwaite classification system (Özyuvaci 1999). The average annual precipitation is $1038.7 \mathrm{~mm}$, mostly concentrated between October and March. The average annual temperature is $9.5^{\circ} \mathrm{C}$. The warmest month is July with a mean temperature of $18.7^{\circ} \mathrm{C}$, and the coldest is January with a mean temperature of $0.4{ }^{\circ} \mathrm{C}$. Soils developed mainly from marble, limestone, and schist parent materials.

The study was conducted between 2005 and 2006 and included 31 forest openings, ranging between 848 and $1160 \mathrm{~m}$ a.s.l. in elevation and between 1.44 to 37.73 ha in size (Özcan 2010). All forest openings were located on a flat terrain and were surrounded by beech stands or a mixture stand of different forest trees including beech and oaks.

\section{Sample collection and analyses}

Forest openings were selected and positioned on a topographical map with a scale of 1:25000 using actual land-use maps, forest management plan, and GIS technology, and divided into three size groups: 0-5 ha, 515 ha, and $>15$ ha. To minimize the edge effect, $20-\mathrm{m}$ long transects were placed across the openings at least $25 \mathrm{~m}$ apart from the forest edge.

Soil samples were collected at $0-20 \mathrm{~cm}$ soil depth along the transects. The number of soil samples collected in each gap varied depending on its size. For gaps smaller than 2.1 ha, samples were collected every $4 \mathrm{~m}$ along a single transect, while for gaps larger 2.1 ha two transects were established and five soil samples taken for each. A total of 120 soil samples were collected from the 0-5 ha gaps, 90 samples from the 5-15 ha gaps and 70 samples from the $>15$ ha gaps.

Samples were air-dried, sieved through a 2 $\mathrm{mm}$ mesh, and analyzed for $\mathrm{EC}$ and $\mathrm{pH}$ (soil/water ratio of 1/5) using a WTW Multiline $\mathrm{P} 4$ universal meter, and total $\mathrm{N}^{+3}$ by LECO FP-328 model full automatic $\mathrm{N}^{+3}$ measurement device. Exchangeable $\mathrm{Na}^{+}, \mathrm{K}^{+}$, $\mathrm{Ca}^{+2}$, and $\mathrm{Mg}^{+2}$ were extracted from soil samples using $1 \mathrm{~N}$ ammonium acetate solution and measured using a Shimadzu 1 6601-F (6600) model atomic absorption equipment (APHA-AWWA-WPCF 1975). Extractable $\mathrm{P}_{-} \mathrm{PO}_{4}^{-3}$ was determined according to the molibdophosphoric blue color method using a Beckman DU 530 model UV spectrophotometer at $660 \mathrm{~m} \mu$ wavelength as milligram per liter (Ministry of Forestry 1994). In order to estimate soil OM content, soil organic carbon was measured using the Walkley and Black method, and multiplied by a conversion factor of 1.72 (Jackson 1958, SERAIEG-6*1 1995, Muscolo et al. 2007).

\section{Experimental design and analysis}

The experiment was arranged in a two-way factorial, completely randomized block design with sub sampling. Factors were gap size (3 levels: $0-5$ ha, 5-15 ha, and $>15$ ha) and surrounding stand type (2 levels: beech stand and a mixture stand of different forest trees including beech and oak trees). Analysis of variance (ANOVA) was carried out, and differences among means were verified by the Tukey's test $(\alpha=0.05)$. In order to meet the assumption of normality and homoscedasticity among treatments, arcsine transformation was applied on percentage data and square root transformation on numerical values, whenever necessary (Zar 1996).

\section{Results}

Mean $\mathrm{pH}$ values averaged over the surrounding forest stand types were 5.93, 5.80, 5.96 for gaps with sizes $0-5$ ha, 5-15 ha, and $>15$ ha, respectively, with no significant differences after ANOVA $(\mathrm{P}=0.184)$. Contrastingly, surrounding forest vegetation types affected soil $\mathrm{pH}$ significantly $(\mathrm{P}=0.044)$, with mean values of 5.93 and 5.87 for gaps surrounded with beech and mixed forests, respectively. Significant interaction was found between gap size and the surrounding forest type for soil $\mathrm{pH}(\mathrm{P}<0.001$ - Fig. 2a). Moreover, differences in mean $\mathrm{pH}$ values between beech and mixed stands were significant in gaps larger than 5 ha after Tukey's test (Fig. 2a).

Soil EC values were significantly affected by the size of forest openings $(\mathrm{P}<0.001)$, with mean values of 209,163 , and 154 $\mu$ mhos $\mathrm{cm}^{-1}$ for the gaps of 0-5 ha, 5-15 ha, and $>15$ ha, respectively. Soils of the latter 
Fig. 2 - Mean soil $\mathrm{pH}$ (a), $\mathrm{EC} \mathrm{(b),} \mathrm{OM} \mathrm{(c),} \mathrm{and} \mathrm{Na}^{+}$(d) values in forest gaps of different sizes surrounded with different forest types. Different letters indicate significant differences among the means after Tukey's test $(\mathrm{P}<0.05)$. Error bars represent the standard error of the mean.
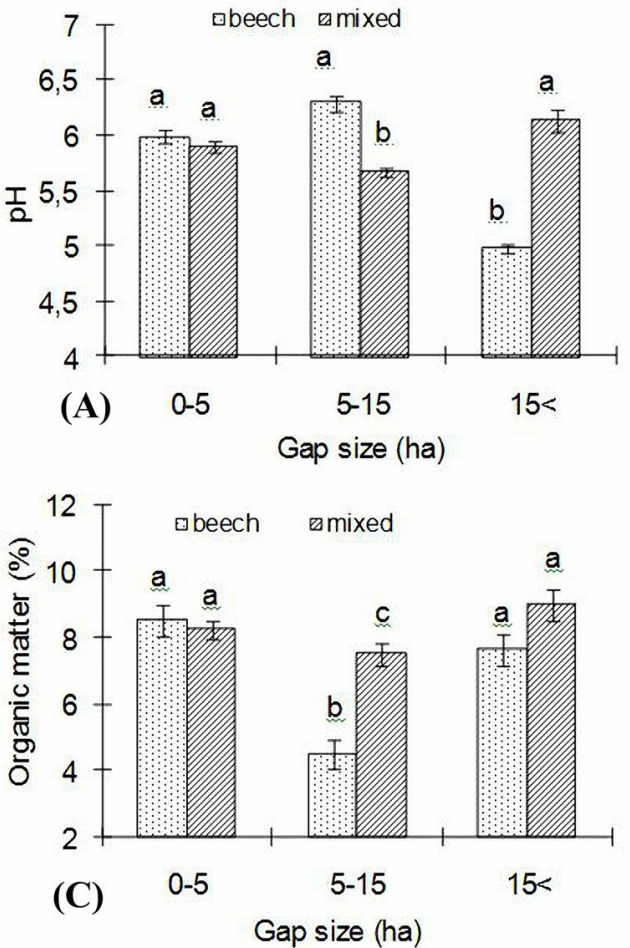
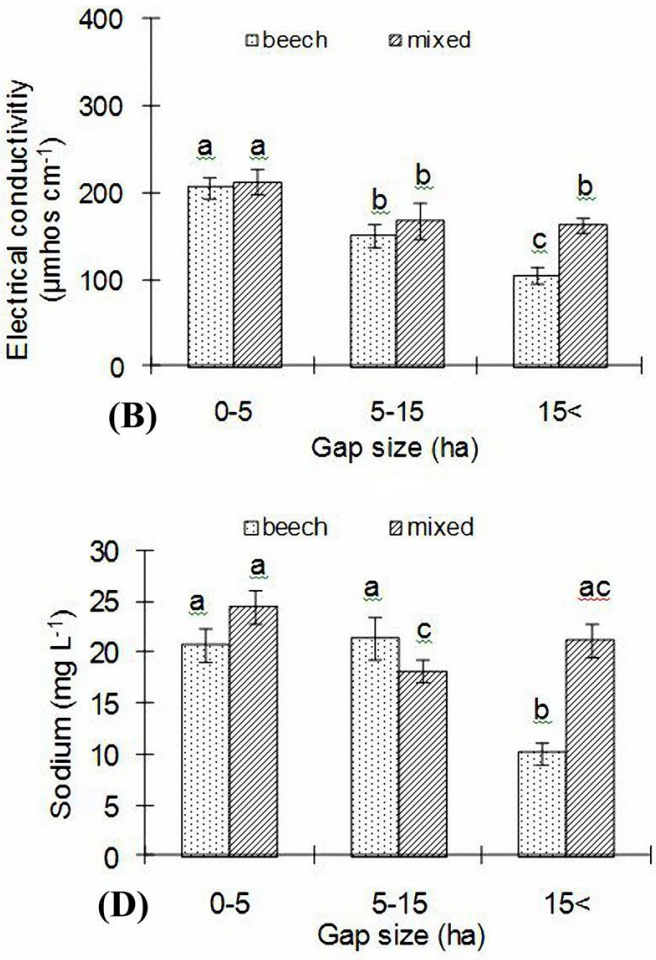

two classes had similar though significantly lower EC values than soils from $0-5$ ha forest gaps $(P=0.001)$. EC values were similar in the openings surrounded by both forest vegetation types, with means of $181 \mu$ mhos $\mathrm{cm}^{-1}$ for gaps surrounded by beech forests and $180 \mu \mathrm{mhos} \mathrm{cm}^{-1}$ for gaps surrounded by mixed forest $(P=0.331)$. Differences in mean EC values between the surrounding forest types were significant only in gaps $>15$ ha $(\mathrm{P}<0.001$ - Fig. 2b). As for this gap size class, gaps surrounded by mixed stands had a greater EC than those surrounded by beech stands. On the other hand, a decreasing trend in mean EC values was observed as the gap size increases for both forest types, though it was statistically significant only for gaps surrounded by beech forests (Fig. 2b).

Soil OM content showed significant changes with respect to the forest gap sizes $(\mathrm{P}<$ 0.001 ), with mean values of $8.37 \%$ for $0-5$ ha gaps, $6.85 \%$ for $5-15$ ha gaps, and 8.78 $\%$ for $>15$ ha gaps. However, no significant differences were detected between 0-5 ha and $>15$ ha openings as for soil OM content Surrounding forest type had also a significant effect on soil $\mathrm{OM}$ values $(\mathrm{P}=0.003)$, and openings surrounded by mixed forest had significantly greater OM content $(8.21$ $\%)$ than those located within the beech forest $(7.47 \%)$. On the other hand, there was significant difference only between 5-15 ha gaps surrounded by beech forest and mixed forest for the soil $\mathrm{OM}$ content $(\mathrm{P}<0.002$; Fig. 2c).

The size of the forest openings analyzed had a significant effect on all cations inve- stigated $(\mathrm{P}<0.05)$, revealing a similar trend for all cations with respect to the gap size. When the surrounding forest types were compared, soils in the gaps located within the mixed forest showed greater $\mathrm{K}^{+}, \mathrm{Na}^{+}$, $\mathrm{Ca}^{+2}$ and $\mathrm{Mg}^{+2}$ concentrations than soils in the gaps within the beech forest.

$\mathrm{K}^{+}$concentration increased significantly as the gap size increases, from $83.88 \mathrm{mg} \mathrm{L}^{-1}$ in the $0-5$ ha gap to $134.64 \mathrm{mg} \mathrm{L}^{-1}$ in the $>15$ ha. Furthermore, the average $\mathrm{K}^{+}$concentrations in the soil showed significant differences between the surrounding forest types, being $85.69 \mathrm{mg} \mathrm{L}^{-1}$ in gaps surrounded by beech forest and $115.29 \mathrm{mg} \mathrm{L}^{-1}$ in gaps surrounded by mixed forest. In contrast to $\mathrm{K}^{+}$, $\mathrm{Na}^{+}$concentration decreased significantly as forest gap size increased $(\mathrm{P}<0.001)$, averaging 22.72, 18.85 and $19.57 \mathrm{mg} \mathrm{L}^{-1}$ for soils in the $0-5$ ha, $5-15$ ha, and $>15$ ha gaps, respectively. Soils in the 5-15 ha and $>15$ ha gaps had similar and significantly lower $\mathrm{Na}^{+}$ values than soils in the $0-5$ ha openings. Moreover, surrounding forest vegetation types also significantly affected soil $\mathrm{Na}^{+}$concentration in the gaps $(\mathrm{P}=0.004)$. The opening surrounded by mixed forest had a mean $\mathrm{Na}^{+}$ value of $21.08 \mathrm{mg} \mathrm{L}^{-1}$, whereas those surrounded by beech forest had an average of $19.66 \mathrm{mg} \mathrm{L}^{-1}$. Significant interaction was found between the surrounding forest vegetation type and the gap size for soil $\mathrm{Na}^{+}$concentration $(\mathrm{P}<0.001)$. When the gap sizes were compared based on the surrounding forest types, the soil in the $>15$ ha gap of the beech forest had the lowest $\mathrm{Na}^{+}$concentration compared to soils in other gaps of both beech and mixed forests. Additionally, there were significant differences between the surrounding forest types for the 5-15 ha and $>15$ ha gap sizes, but not for the $0-5$ ha (Fig. $2 d)$. There were also no significant differences between soils in the $0-5$ ha and $>15$ ha openings, and between soils in the 5-15 ha and $>15$ ha gaps in the mixed forest, as well as between soils in the $0-5$ ha and 5-15 ha gaps in the beech forest (Fig. 2d).

Average $\mathrm{Ca}^{+2}$ concentration differed significantly according to the surrounding forest cover type $(\mathrm{P}=0.001)$, averaging 695.85 and $758.89 \mathrm{mg} \mathrm{L}^{-1}$ for soils in the beech and in the mixed forest gaps, respectively. Similarly, gap size affected soil $\mathrm{Ca}^{+2}$ content significantly $(\mathrm{P}=0.003) . \mathrm{Ca}^{+2}$ values did not show any regular pattern as the gap size increased, averaging 771.36, 619.24 and $838.30 \mathrm{mg} \mathrm{L}^{-1}$ in the $0-5$ ha, $5-15$ ha and $>15$ ha gaps, respectively. Soils from the $>15$ ha gap of mixed forests had the highest and those in the same gap size of beech forests had the lowest $\mathrm{Ca}^{+2}$ concentration compared to rest of the gaps $(\mathrm{P}<0.001$; Fig. $3 a)$. When the gap size was considered along with the surrounding cover type, soils in the 0-5 ha and 5-15 ha openings in beech stands had similar but significantly greater $\mathrm{Ca}^{+2}$ values than soils in the $>15$ ha gap surrounded by the same forest cover, whereas the soils in the $>15$ ha gap in the mixed forest had significantly greater $\mathrm{Ca}^{+2}$ value than the 5-15 ha gap size of the same forest vegetation cover (Fig. 3a).

Mean $\mathrm{Mg}^{+2}$ values were 59.46, 76.21, and $123.96 \mathrm{mg} \mathrm{L}^{-1}$ for the soils in the $0-5$ ha, 5- 

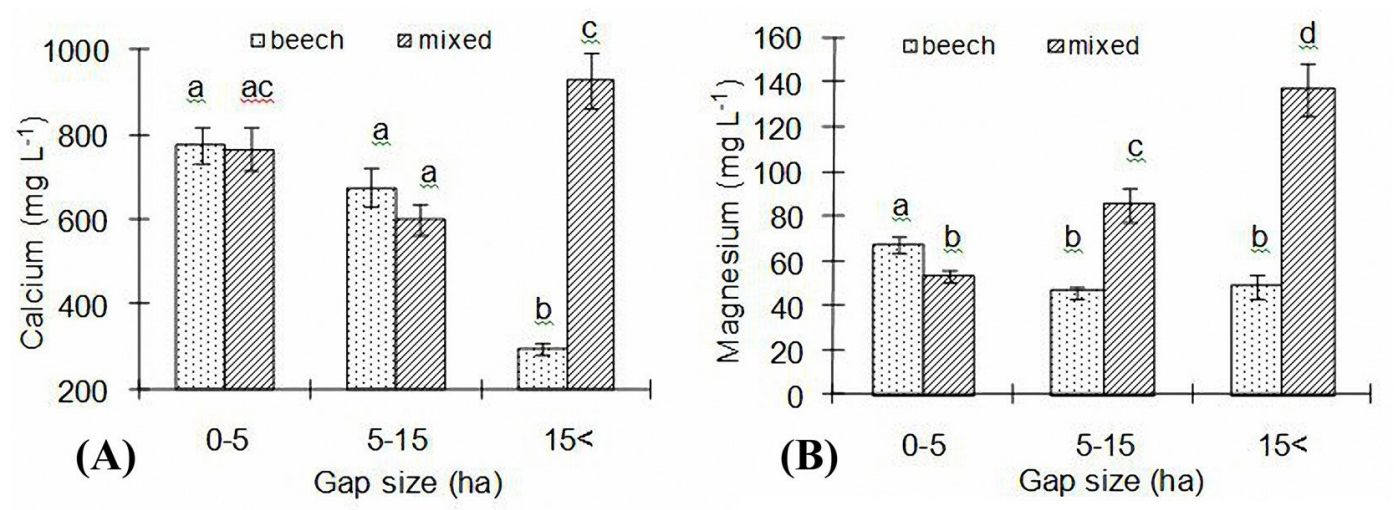

Fig. 3 - Average $\mathrm{Ca}^{+2}$ (a), $\mathrm{Mg}^{+2}(\mathrm{~b}), \mathrm{N}^{+3}$ (c), and $\mathrm{P}_{-} \mathrm{PO}_{4}^{-3}$ (d) values in the forest gaps of different size surrounded with different forest types. Different letters indicate significant differences among the means after Tukey's test $(\mathrm{P}<0.05)$. Error bars represent the standard error of the mean.
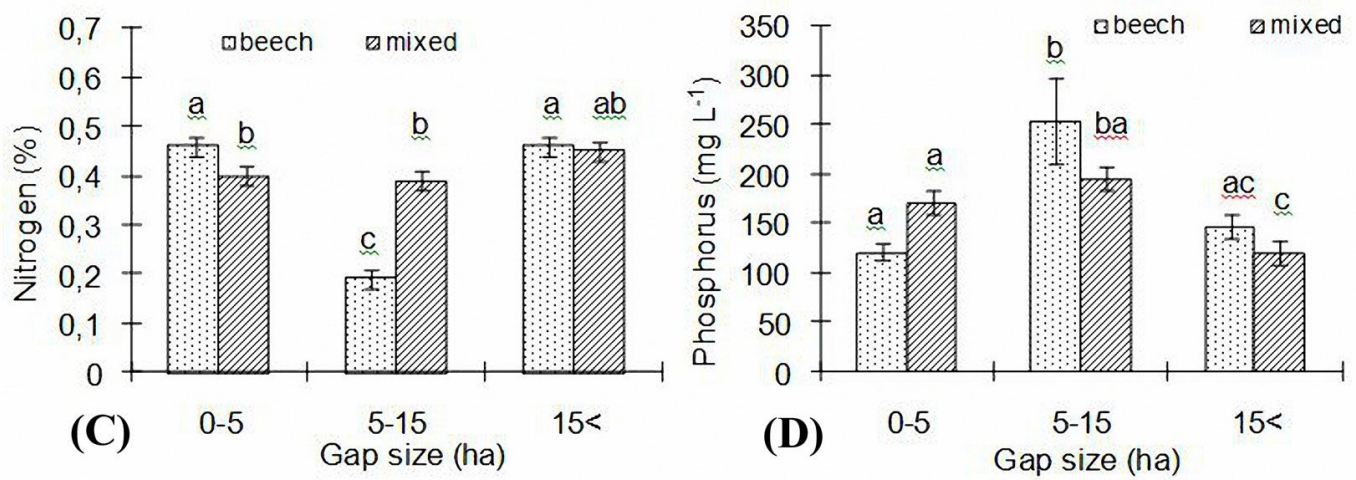

15 ha and $>15$ ha gap sizes, respectively, and soils in the 0-5 ha and 5-15 ha gaps had similar but significantly lower $\mathrm{Mg}^{+2}$ concentrations than soils in the $>15$ ha gap $(\mathrm{P}<$ $0.032) . \mathrm{Mg}^{+2}$ concentration was also significantly greater in soils from the mixed forest gaps $\left(90.38 \mathrm{mg} \mathrm{L}^{-1}\right)$ compared to soils from gaps located in beech forests $\left(59.67 \mathrm{mg} \mathrm{L}^{-1}\right.$. $\mathrm{P}<0.001) . \mathrm{Mg}^{+2}$ concentration increased significantly in mixed forest openings soils, while no relationships were found between gap size and $\mathrm{Mg}^{+2}$ concentration for beech forest openings (Fig. 3b).

The surrounding vegetation type did not significantly affect the average $\mathrm{N}^{+3}$ concentration in gap soils, being $0.39 \%$ for soils in beech forest gaps and $0.41 \%$ for soils in the mixed forest openings. The gap size had a significant effect on $\mathrm{N}^{+3}$ content $(\mathrm{P}<0.001)$, with mean $\mathrm{N}^{+3}$ level of $0.43 \%, 0.35 \%$ and $0.45 \%$ in soils from the $0-5$ ha, $5-15$ ha, and $>15$ ha openings, respectively. $\mathrm{N}^{+3}$ concentrations in soils from mixed forest gaps were similar, while those in beech forest gaps differed significantly. The soil in the 5-15 ha openings from the beech forest had the lowest $\mathrm{N}^{+3}$ value (Fig. 3c).

The overall mean $\mathrm{P}_{-} \mathrm{PO}_{4}{ }^{-3}$ concentration differed significantly with respect to forest gap sizes $(\mathrm{P}<0.001)$. The $5-15$ ha gap had the highest value $\left(208.6 \mathrm{mg} \mathrm{L}^{-1}\right)$ followed by the $0-5$ ha gap $\left(147.42 \mathrm{mg} \mathrm{L}^{-1}\right)$ and the $>15$ ha gap (123.56 mg L $\left.{ }^{-1}\right)$. Contrastingly, surrounding vegetation did not show any significant effect on $\mathrm{P}_{-} \mathrm{PO}_{4}^{-3}$ values in the soil (155.13 vs. $163.67 \mathrm{mg} \mathrm{L}^{-1}$ for beech and mi- xed forest gaps, respectively). Soil $\mathrm{P}_{-} \mathrm{PO}_{4}^{-3}$ content in the gaps surrounded by both forest types showed a similar trend. The 5-15 ha beech forest opening had significantly greater soil $\mathrm{P}_{-} \mathrm{PO}_{4}^{-3}$ content than the other two gap classes, whereas the soil in the $>15$ ha mixed forest gap had a lower $\mathrm{P}_{-} \mathrm{PO}_{4}^{-3}$ content than soils from the other two gaps of the same forest type $(P=0.008$ - Fig. 3d). Among the gaps surrounded by mixed forest, the $>15$ ha gap had the lowest $\mathrm{P}-\mathrm{PO}_{4}{ }^{-3}$ value while among the gaps surrounded by beech forest, the 5-15 ha gap had the highest P$\mathrm{PO}_{4}^{-3}$ value (Fig. 3d). Also, surrounding forest types did not differ significantly for the same gap size.

\section{Discussion}

The present study revealed that gap size and the surrounding forest canopy may affect differently the soil chemistry in forest openings. However, no regular patterns were observed for soil chemical properties with respect to gap size. Our results are not always in agreement with those of earlier studies, though similar findings for soil $\mathrm{pH}$ are reported by Muscolo et al. (2007) and Ritter et al. (2005). On the contrary, Muscolo et al. (2010) and Arunachalam \& Arunachalam (2000) found that soil $\mathrm{pH}$ was slightly higher in small gaps, while Kooch et al. (2010) and Haghverdi et al. (2012) reported higher $\mathrm{pH}$ values for large openings as compared to medium gaps. In addition, Chunyu \& Xiuhai (2007) found a positive correlation between soil $\mathrm{pH}$ and gap size. Since soil $\mathrm{pH}$ affects also the form and availability of the organic matter in the soil and its associated processes (e.g., physico-chemical reactions, microorganism activities, and biological growth, etc), patterns of the soil $\mathrm{pH}$ and $\mathrm{OM}$ were similar in the $0-5$ ha and $>15$ ha forest openings. According to the literature (Alfredsson et al. 1998, Turk et al. 2008), litter decomposition from broadleaves can make soil neutral or slightly acidic, as measured in the current study. In general, temperature and moisture conditions change after gap formation (Rhoades et al. 2004, Ritter et al. 2005, Scharenbroch \& Bockheim 2007), influencing the OM levels and turnover rates in the forest gaps. Although soil OM is the main source of total $\mathrm{N}^{+3}$ and other nutrients, OM content and soil chemical parameters did not show a similar trend, except for $\mathrm{N}^{+3}$ and EC. The 515 ha gaps both in the beech and mixed forests had significantly lower OM than the large gaps, as found by Muscolo et al. (2010), Haghverdi et al. (2012), and Kooch et al. (2010). At the same time, Muscolo et al. (2007) and Arunachalam \& Arunachalam (2000) reported lower OM content for soils in large gaps compared to small openings. Similarly, higher $\mathrm{N}^{+3}$ values were measured in the soil from large gaps in some studies (Kooch et al. 2010, Haghverdi et al. 2012) and from small gaps in others (Arunachalam \& Arunachalam 2000, Muscolo et al. 2007 2010). Soil $\mathrm{P}_{-} \mathrm{PO}_{4}^{-3}$ concentration decreased significantly with increasing the gap size from $5-15$ ha to $>15$ ha, in agreement with Muscolo et al. (2007). Although some stu- 
dies reported that a higher solar radiation due to a larger gap size may accelerate the OM decomposition and cause an increase in the amount of soil nutrients, Arunachalam \& Arunachalam (2000), Scharenbroch \& Bockheim (2007), and Thiel \& Perakis (2009) did not find any significant gap size effect on the physical and chemical properties of most soils examined.

In the present study, no regular patterns were detected in the concentration of soil nutrients in relation to the gap size. The larger amount of rainfall occurring in large gaps as compared to small gaps may lead to higher nutrient losses by leaching (Arunachalam \& Arunachalam 2000). Thus, an increase in the opening size can potentially enhance the leaching of soil nutrients in the gaps (Bartsch 2000, Scharenbroch \& Bockheim 2007, Kooch et al. 2010). Additionally, larger gaps can receive more solar energy and have higher air and soil temperatures, and lower soil moisture due to higher evaporation than smaller gaps (Muscolo et al. 2007, 2010). Under these conditions, litter decomposition and microbial activities can be limited and soil fertility and nutrient availability can decrease in the large openings (Arunachalam \& Arunachalam 2000, Prescott 2002).

\section{Conclusion}

Forest management activities can influence the nutrient content and availability in the soil of forest openings. In this study, gap size and surrounding forest canopy significantly affected soil chemical properties and hence soil fertility and nutrient availability in the forest gaps. Surrounding forest cover types had a significant effect on most of the soil chemical properties studied except for soil $\mathrm{pH}$, while gap size did not have a significant effect on EC and levels of $\mathrm{N}^{+3}$ and P$\mathrm{PO}_{4}{ }^{-3}$. Surrounding forest cover types had a much more significant effect on chemical characteristics of the soil than gap size.

As expected, soils in the mixed forest gaps had greater amounts of OM and cations (except for $\mathrm{N}^{+3}$ and $\mathrm{P}_{-} \mathrm{PO}_{4}^{-3}$ ) than soils in the beech forest gaps. Since large gaps receive more solar radiation and precipitation compared to small ones, it was hypothesized that the decomposition rate could be faster and soils could be richer in cations in the $>15$ ha gap. In contrast to this expectation, soils in the $>15$ ha gap had only significantly greater $\mathrm{K}^{+}$and $\mathrm{Mg}^{+2}$ ions than the other two gap sizes. Further studies are needed to determine the critical gap size not causing an increase in the nutrient concentration in the soil solution as a result of leaching and not limiting the decomposition rate due to great changes in the gap microclimate.

\section{References}

Alfredsson H, Condron LM, Clarholm M, Davis MR (1998). Changes in soil acidity and organic matter following the establishment of conifers on former grasslandin New Zealand. Forest Ecology and Management 112: 245-252. - doi: 10.1016/ S0378-1127(98)00346-6

APHA-AWWA-WPCF (1975). Standard methods for the examination of water and wastewater (14 ${ }^{\text {th }}$ edn). American Public Health AssociationAmerican Water Works Association-Water Pollution Control Federation, Washington, DC, USA, pp. 1193.

Alan M, Ekiz H (2001). A vegetation survey in forest range of Küredagi-Bala. Ankara University Faculty of Agriculture, Journal of Agricultural Science 4: 62-69. [in Turkish with English abstract]

Arunachalam A, Arunachalam K (2000). Influence of gap size and soil properties on microbial biomass in a subtropical humid forest of northeast India. Plant and Soil 223: 185-193. - doi: 10.1023/A:1004828221756

Augusto L, Bonnaud P, Ranger J (1998). Impact of tree species on forest soil acidification. Forest Ecology and Management 105: 67-78. - doi: 10.1016/S0378-1127(97)00270-3

Babalik A (2008). Range vegetation characteristics and their variation in relation with some soil properties and topographic factors in Isparta region. PhD thesis, Süleyman Demirel University, Institute of Science, Isparta, Turkey, pp. 164. [In Turkish with English abstract]

Bartsch N (2000). Element release in Beech ( $F a$ gus sylvatica $\mathrm{L}$.) forest gaps. Water, Air, and Soil Pollution 122: 3-16. - doi: 10.1023/A:10052 65505479

Bilgili A (2007). Determination of vegetation and forage quality in forest gap rangelands of Sarikamis. Master thesis, Atatürk University, Institute of Science, Erzurum, Turkey, pp. 67. [in Turkish with English abstract]

Carlson DW, Groot A (1997). Microclimate of clear-cut, forest interior, and small openings in trembling aspen forest. Agricultural and Forest Meteorology 87: 313-329. - doi: 10.1016/S01681923(95)02305-4

Chunyu Z, Xiuhai Z (2007). Soil properties in forest gaps and under canopy in broad-leaved Pinus koraiensis forests in Changbai Mountainous Region China. Frontiers of Forestry in China 2 (1): 60-65.

Fernald A, Gökbulak F, Ramirez H, Van Leeuwen D (2009). Soil moisture and temperature responses to tree thinning in central New Mexico. In: Proceedings of the " $62^{\text {nd }}$ Society for Range Management Annual Meeting". Albuquerque (New Mexico, USA) 8-12 February 2009. Society for Range Management, Albuquerque, New Mexico, USA, pp. 06-3.

Frost WE, Edinger SB (1991). Effects of tree canopies on soil characteristics of annual rangeland. Journal of Range Management 44 (3): 286288. - doi: $10.2307 / 4002959$

Galhidy L, Mihok B, Hagyo A, Rajkai K, Standovar T (2006). Effects of gap size and associated changes in light and soil moisture on the understory vegetation of Hungarian beech forest. Plant Ecology 183: 133-145. - doi:

\subsection{7/s11258-005-9012-4}

Gökbulak F, Özcan M (2008). Hydro-physical properties of soils developed from different parent materials. Geoderma 145: 376-380. - doi: 10.1016/j.geoderma.2008.04.006

Hagen-Thorn A, Callesen I, Armolaitis K, Nihlgard B (2004). The impact of six European tree species on the chemistry of mineral top soil in forest plantations on former agricultural land. Forest Ecology and Management 195: 373-384. doi: 10.1016/j.foreco.2004.02.036

Haghverdi K, Kiadaliri H, Sagheb-Talebi K, Kooch Y (2012). Variability of plant diversity and soil features following gap creation in Caspian beech forests of Iran. Annals of Biological Research 3 (9): 4622-4635. [online] URL: http:// scholarsresearchlibrary.com/ABR-vol3-iss9/AB R-2012-3-9-4622-4635.pdf

Jackson ML (1958). Soil chemical analysis. Prentice Hall Inc., Englewood Cliffs, NJ, USA, pp. 521.

Kooch Y, Hosseini SM, Mohammadi J, Hojjati SM (2010). The effects of gap disturbance on soil chemical and biochemical properties in a mixed beech-hornbeam forest of Iran. Ecologica Balkanica 2:39-56.

Kooch Y, Hosseini SM, Zaccone C, Jalilvand H, Hojjati SM (2012). Soil organic carbon sequestration as affected by afforestation: the Darab Kola forest (north of Iran) case study. Journal of Environmental Monitoring 14:2438-2446. - doi: 10.1039/c2em30410d

Ministry of Forestry (1994). Seminar on the foundation principles of forest soil laboratories and laboratory techniques. Eskisehir (Turkey) 4-8 April 1994. Eskisehir Forest Soil Laboratory Directorate, Eskisehir, Turkey, pp. 216. [in Turkish]

Morecroft MD, Taylor ME, Oliver HR (1998). Air and soil microclimates of deciduous woodland compared to an open site. Agricultural and Forest Meteorology 90: 141-156. - doi: 10.1016/ S0168-1923(97)00070-1

Muscolo A, Sidari M, Mercurio R (2007). Influence of gap size on organic matter decomposition microbial biomass and nutrient cycle in Calabrian pine (Pinus laricio Poiret.) stands. Forest Ecology and Management 242: 412-418. - doi: 10.1016/j.foreco.2007.01.058

Muscolo A, Sidari M, Bagnato S, Mallamaci C, Mercurio R (2010). Gap size effects on aboveand below-ground processes in a silver fir stand. European Journal of Forest Research 129: 355365. - doi: 10.1007/s10342-009-0341-z

Özcan M (2010). Range vegetation characteristics of sub-alpine forest range in Yuvacik watershed, Izmit. $\mathrm{PhD}$ thesis, Istanbul University, Institute of Science, Istanbul, Turkey, pp. 160. [In Turkish with English abstract]

Özyuvaci N (1999). Meteorology and climatology. Istanbul University publication number no. 4196, Faculty of Forestry publication number no. 460, Dilek offset matbaacilik, Istanbul, Turkey, pp. 369. [In Turkish]

Prescott C (2002). The influence of the forest canopy on nutrient cycling. Tree Physiology 22: 
1193-1200. - doi: 10.1093/treephys/22.15-16.11 93

Renaud V, Rebetez M (2009). Comparison between open-site and below-canopy climatic conditions in Switzerland during the exceptionally hot summer of 2003. Agricultural and Forest Meteorology 149: 873-880. - doi: 10.1016/j.agrformet.2008.11.006

Rezaei AS, Gilkes RJ (2005). The effects of landscape attributes and plant community on soil chemical properties in rangelands. Geoderma 125: 167-176. - doi: 10.1016/j.geoderma.2004.0 7.010

Rhoades CC, Miller SP, Shea MM (2004). Soil properties and soil $\mathrm{N}$ dynamics of prairie-like forest openings and surrounding forests in Kentucky's Knobs Region. The American Midland Naturalist 152 (1): 1-11. - doi: 10.1674/00030031(2004)152[0001:SPASND]2.0.CO;2

Ritter E (2005). Litter decomposition and nitrogen mineralization in newly formed gaps in a Danish beech (Fagus sylvatica) forest. Soil Biology and Biochemistry 37: 1237-1247. - doi: 10.1016/j. soilbio.2004.11.020

Ritter E, Dalsgaard L, Einhorn KS (2005). Light, temperature and soil moisture regimes following gap formation in semi-natural beech-dominated forest in Denmark. Forest Ecology and Management 206: 15-33. - doi: 10.1016/j.foreco.2004. 08.011

Sariyildiz T, Anderson JM, Kucuk M (2005). Effects of tree species and topography on soil chemistry, litter quality, and decomposition in Northeast Turkey. Soil Biology and Biochemistry 37: 1695-1706. - doi: 10.1016/j.soilbio.20 05.02.004

Scharenbroch BC, Bockheim JG (2007). Impacts of forest gaps on soil properties and processes in old growth northern hardwood-hemlock forest. Plant Soil 294: 219-233. - doi: 10.1007/s11104007-9248-y

SERA-IEG-6*1 (1995). Soil testing and plant analysis (Mitchell CC, Everest JW eds). Southern Regional Fact Sheet, Dept. Agronomy \& Soils, Auburn University, AL, USA.

Tekeli S, Mengül Z (1991). Effect of topography on the botanical composition and yield in forest rangelands. In: Proceedings of the " 2 nd $C$ Congress on Pasture-rangeland and forage plants". Ege University (Izmir, Turkey) 28-31 May 1991,pp. 139-149. [In Turkish]

Thiel AL, Perakis SS (2009). Nitrogen dynamics across silvicultural canopy gaps in young forests of western Oregon. Forest Ecology and Manage- ment 258: 273-287. - doi: 10.1016/j.foreco.20 09.04.015

Turk TD, Schmidt MG, Roberts NJ (2008). The influence of bigleaf maple on forest floor and mineral properties in a coniferous forest in coastal British Columbia. Forest Ecology and Management 255: 1874-1882. - doi: 10.1016/j.foreco. 2007.12.016

Uluocak N (1974). Quantitative botanical analyses of range vegetation in the vicinity of Kirklareli and some site factors affecting its composition. $\mathrm{PhD}$ thesis, Istanbul University, Faculty of Forestry, Istanbul, Turkey, pp. 132. [in Turkish with English abstract]

Vesterdal L, Schmidt IK, Callesen I, Nilsson LO, Gundersen P (2008). Carbon and nitrogen in forest floor and mineral soil under six common European tree species. Forest Ecology and Management 255: 35-48. - doi: 10.1016/j.foreco. 200 7.08 .015

Wang QK, Wang SL (2007). Soil organic matter under different forest types in Southern China. Geoderma 142: 349-356. - doi: 10.1016/j.geoderma.2007.09.006

Zar JH (1996). Biostatistical analysis ( $3^{\text {rd }}$ edn). Prentice Hall, Upper Saddle River, New Jersey, USA, pp. 662. 